\title{
Chapter 3 \\ Boserup's Theory on Technological Change as a Point of Departure for the Theory of Sociometabolic Regime Transitions
}

\author{
Marina Fischer-Kowalski, Fridolin Krausmann, Andreas Mayer \\ and Anke Schaffartzik
}

\begin{abstract}
This chapter is devoted to the core theoretical propositions unfolded in E. Boserup's 1981 book Population and Technological Change and represents an attempt to take these ideas further. The 1981 book makes an effort to provide a theoretical explanation for the full course of human history, from hunting and gathering communities through various stages of agricultural societies right into the industrial transformation. First we re-examine her own data, confirming her core thesis about average agricultural output per area risingwith population density at the expense of declining output per labour hour, but demonstrating a strong discontinuity at the industrial end of her technology scale.Clearly, what is measured at this end, the transition to fossil fuel use in agriculture, leads to saving labour. Second, we explain our theory of sociometabolic regime transitions and try to show how much this theory learned from Boserup. This theory, though, supposes that it makes a fundamental difference if societies base practically all of their processes on solar energy, its conversion into plant biomass and, consequently, on agriculture as the key energy supply sector, or if they base their processes on fossil fuel energy sources - this is a qualitative leap beyond what Boserup introduces as gradual distinctions. In a third part, based on our comparative research on resource use, we elaborate on three examples for the lasting validity of Boserup's arguments: on the non-linearity between population growth and land requirements, on the transferability of this thesis to other resources as well, and finally on the persistent relevance of population density as key factor allowing for lower resource consumption. This chapter confirms Boserup's role as
\end{abstract}

\footnotetext{
M. Fischer-Kowalski $(\bowtie) \cdot$ F. Krausmann · A. Mayer · A. Schaffartzik Institute of Social Ecology Vienna (SEC), Alpen-Adria University,

Schottenfeldgasse 29, 1070 Vienna, Austria

e-mail: marina.fischer-kowalski@aau.at

F. Krausmann

e-mail: fridolin.krausmann@aau.at

A. Mayer

e-mail: andreas.mayer@aau.at

A. Schaffartzik
e-mail: anke.schaffartzik@aau.at
}

M. Fischer-Kowalski et al. (eds.), Ester Boserup's Legacy on Sustainability, 
an eminent theorist and analyst of the development trajectory of agrarian societies, but also points to her weakness in understanding the industrial transformation.

Keywords agricultural change - population density · industrial transformation . sociometabolic regimes · land and labour intensity

\subsection{Introduction}

Ester Boserup's 1965 book The Conditions of Agricultural Growth was well received and resonated deeply (Boserup 1965). In contrast, Boserup's most mature and comprehensive book, 1981's Population and Technological Change: A study of Long-Term Trends (Boserup 1981), in all its complexity, seems to have received less attention.

This chapter is devoted to the core theoretical propositions unfolded in this 1981 book and represents an attempt to take these ideas further. In her work Population and Technological Change, Boserup not only had the ambition to elaborate and generalise her ideas from 1965, she also made a number of attempts to explore the validity of her arguments using quantitative analysis. She did so mainly using national-level data (skilfully digging out the information on the few countries for which the data were available at the time), analysing the interrelations of her two main variablespopulation density presumably as the independent variable and technological change as the dependent variable - as well as the joint impact of both on other variables. This methodological approach that she helped pioneer is still very common, particularly in the context of reports from international organizations, but the data situation has, of course, much improved since.

What we attempt to show in this chapter is not only that the theory of sociometabolic regime transitions genuinely builds upon Boserupian foundations (even if it contradicts her preoccupation with gradualism) but also that data generated in the context of material and energy flow accounting (Haberl et al. 2004) are very suitable for putting her key propositions to empirical tests.

\subsection{Boserup's Main Theoretical Propositions, and her Efforts at an Empirical Proof}

In the preface, Boserup (1981) describes the claims of this book in relation to her book on the conditions of agricultural growth (1965). Because the latter focuses only on agricultural technology, it had to "abstain from the analysis of the effects of technological change on population change. It therefore discussed only the effects of population change, not its causes. This book deals with all types of populationlinked technologies, and I have made an attempt to deal with both sides of the interrelationship." (Boserup 1981, p. ix) Her later book, she says, has a broader 
scope; whereas the earlier book focuses exclusively on agricultural societies, the later volume also deals briefly with pre-agricultural communities and, in much more detail, with societies in early stages of industrialization. However, even in the later book, she makes "no attempt to discuss the most recent technological innovations in the highly industrialised societies." (Boserup 1981, p. x) "This book is not a revision of The Conditions of Agricultural Growth," Boserup points out, "but only an attempt to broaden and deepen it." Discussing the criticisms she received for her previous work, she self-confidently asserts "that I was on the right track and have nothing to regret, so far as the theory is concerned" (ibid.).

In other words, the 1981 book makes an effort to provide a theoretical explanation for the full course of human history, from hunting and gathering communities through various stages of agricultural societies right into the industrial transformation. Its overall structure complies with this ambition: a chapter on the theoretical framework is followed by a historical chapter on population and technology in the ancient world. She then discusses the role of demographic factors in European development and the diffusion of industrial technologies. Finally, she deals with demographic transition and technological change in the Third World.

Her basic theoretical framework for the core interrelation between demographic dynamics and technological development reads as follows (Boserup 1981, p. 5 ff.): Inventions, or the acceptance of spreading inventions, have a strong demand component, and rapid population growth can generate such a demand. Thus, population change induces inventions and technological change and also facilitates technological change: more people available make doing things differently possible. There is also a feedback loop in that technological change leads to further population change.

Increased population density in an area has a dual effect on the availability of lifesustaining natural resources: On the one hand, it makes life easier because it allows for burden sharing in accessing these resources. On the other hand, in the long run, the ratio of natural resources to the population decreases. "One or the other tendency may prevail" (Boserup 1981, p. 5). As a result of both tendencies, an increase in population density "provides an incentive to replace natural resources by labour and capital” (Boserup 1981, p. 6).

These are the key theoretical propositions that lead her through the rich material throughout her book. She operationally defines her key variables: population density and technological change. Both variables are measured at a national level, using the few internationally available data of her time. Density is fairly straightforward: she defines 10 density classes (in persons per $\mathrm{km}^{2}$ each distinguished from the next by factor 2: 0-1, 1-2, 2-4, 4-8 . . 128-256, > 256) that she will later group together.

Next, she specifies technological levels (Boserup 1981, p. 12 ff.). Among the indicators she uses, per capita energy consumption (in coal equivalents), which can be considered practically equivalent to the amount of fossil fuel use, comes first. Next is the number of telephones per 1,000 inhabitants (again in its dependency upon electricity bound to fossil fuel use), an indicator of extending communication beyond the local community and of interconnectedness. Average life expectancy, as an indicator of health infrastructure, food supply and literacy rates, rounds out the set. She ranks the countries by each indicator, constructs an index in which each 


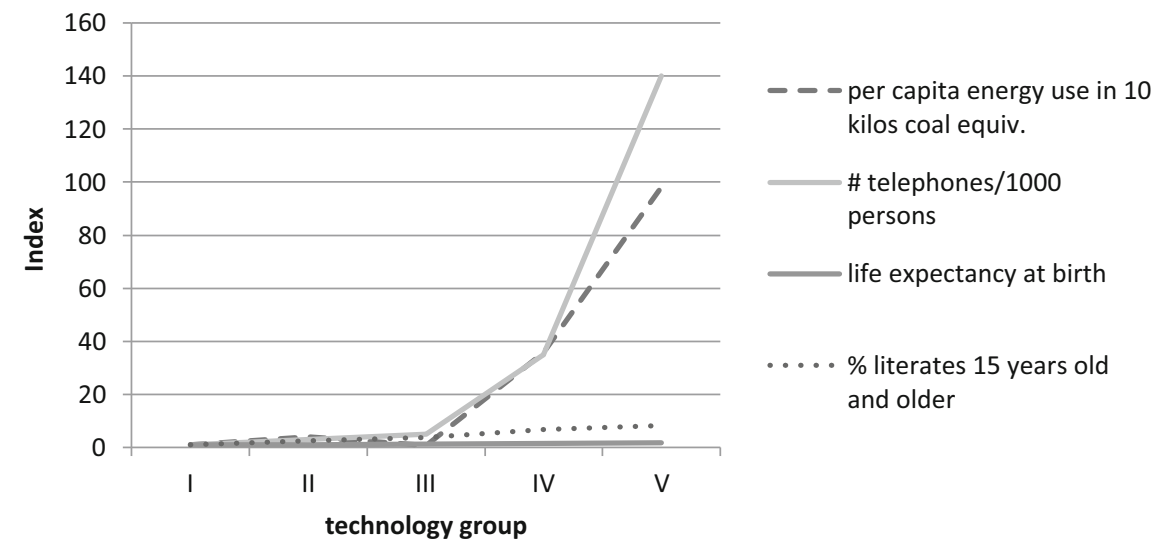

Fig. 3.1 Indicator values by technology level. (According to Boserup 1981, p. 13, Table 2.3; calculated as indices, value of technology level $\mathrm{I}=1$ )

indicator carries equal weight, and finally puts the countries into 5 groups by the resulting index, with each group containing an equal number of countries (for the year 1970) (Fig. 3.1).

Boserup presents the relation between indicators and technology groups in the form of a table. In general, the technology groups exhibit a rise in life expectancy, literacy, and "connectivity" from one group to the next using different levels of fossil fuel inputs. What becomes much more apparent when presented graphically is the relative homogeneity of technology groups I-III according to these indicators. Then, there is an increase through group IV to group V clearly related to fossil energy use. Thus, what she shows here are not the subtle differences within the agrarian regime that were her original focus (differentiation by fallow periods and gradual intensification of land use) but the progressive use of fossil fuels as a source of energy. ${ }^{1}$

In her next step, she puts her core hypothesis of 1965, that high population density, far from making people starve, moves them in a position to advance technologically, to a test with these data. The results (see graph in Fig. 3.2) do not convince her. She feels there is no longer as close a correlation as between population density and high technological levels as "there seems to have been before the industrial revolution" (Boserup 1981, p. 14), but even now she sees a pronounced inverse relationship only happening rarely, recognizing that "it became possible for a sparsely populated area by very rapid technological development to become the leading industrial nation in little more than a century." (Boserup 1981, p. 144)

Clearly, the proportion of high-density countries is highest among the top technology group, but the proportion of low-density countries does not continuously

\footnotetext{
${ }^{1}$ This transition is also reflected in several other tables in chapter 1 (Boserup 1981); there is never a more or less steady increase from group 1 to group 5 . However a consistent pattern can be observed that groups 1-3 are fairly similar and then there is rapid change through 4 to 5 . She fails to register this explicitly.
} 


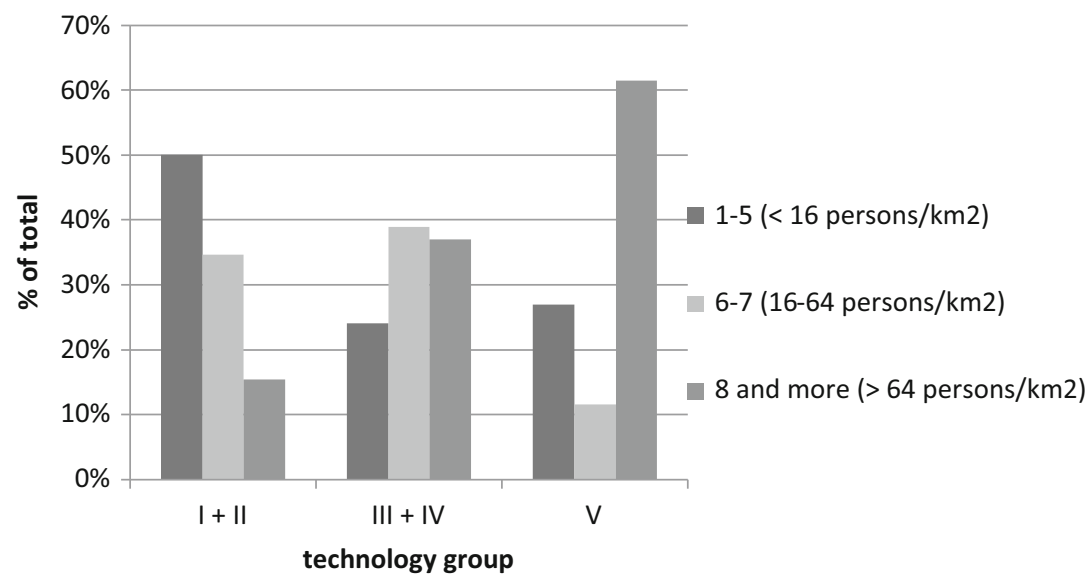

Fig. 3.2 Population density and technological level in 1970 ( 100 countries). (According to Boserup 1981, p. 14, Table 2.5; technology groups as in original)
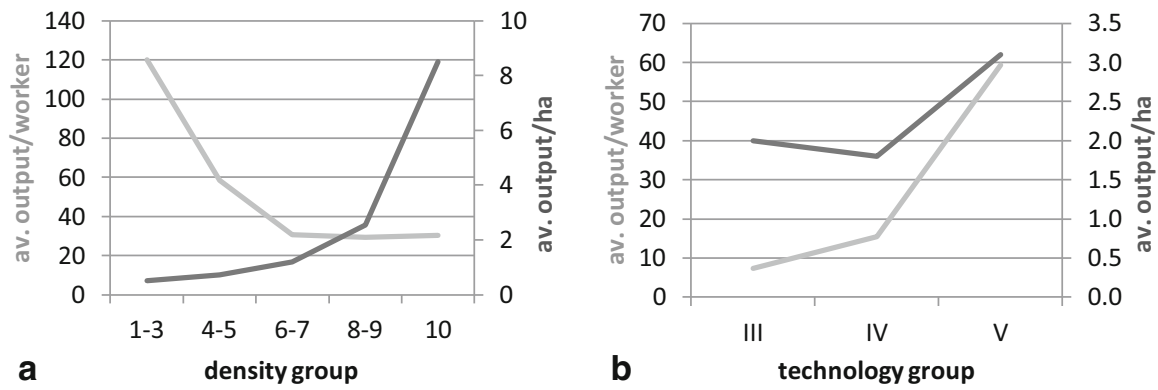

Fig. 3.3 The overall effect of density (a), and technology (b) on output. (According to Boserup 1981, p. 27, Table 3.13; number of countries per cell very small (1-4)

decline with technological advancement - there must be other factors involved as well. The issue could be resolved more easily if she drew a theoretical dividing line between population dynamics and technological advancement under agrarian regime conditions, where her hypothesis is highly plausible and corresponds very well to historical observation, and the roles of population dynamics under industrializing and industrial conditions that are somehow qualitatively different. ${ }^{2}$

Even the findings concerning her core thesis that average agricultural output per area rises in dependency upon population density at the expense of declining output per labour hour confirm her theory, but still there is a strong discontinuity with technology level V, the industrial end of the scale (see Fig. 3.3).

Yield per worker does not depend much on population density but strongly depends on technology. Density plays a role only in technology group V (with output per

\footnotetext{
${ }^{2}$ Practically, of course, this would always be blurred because there is often a protracted transition phase between one system state to the other.
} 
worker declining as predicted). Clearly, what this technology scale measures, i.e., transition to fossil fuel use, reflects itself in an emphasis on saving labour.

From multivariate and bivariate perspectives (Fig. 3.3), one sees output per hectare rise with population density and output per worker decline. This finding confirms Boserup's core theoretical assumption. However, with technology groups, the old assumption does not hold; both output per hectare and output per worker increase with the technological level because a technological level is not defined as improved technology within agricultural society but as the degree of transition towards the use of fossil fuels.

Why does Ester Boserup not draw a dividing line between systems functioning differently, as she herself repeatedly recognises?

She clearly disapproved of the arrogance of modernist exceptionalism in bringing technological innovation and change to "traditional" communities that would otherwise be static. For this reason, perhaps, she opposed the dichotomous distinction of "modern" and "traditional" altogether and introduced a much richer set of qualitative distinctions of food supply systems, differentiated by what she considers the decisive variable for land use intensity: fallow periods (Boserup 1965, p. 15 f., 1981, p. 18 f.). This line of reasoning was highly innovative vis-à-vis the simplistic distinctions of classical political economy between cultivated land and unused land and the derived processes of extension (cultivating additional land) and intensification (increasing output) and was inspirational for contemporary land use science (see Chap. 5 by Erb et al. in this volume). Nevertheless, it still shares with the classics a particular blind spot: an unawareness of the crucial role of sources of energy.

For her, contrary to mainstream thinking, tools and their improvement, as well as input factors such as fertilisers, pesticides and herbicides, play a secondary role. Her core argument, simplified, is that population growth increases density and makes it necessary to find ways to use land more intensively, which is equivalent to reducing fallow periods (up to annual multicropping), which in turn drives technological development; solutions also rely on the availability of more people and more labour power.

It makes a fundamental difference if societies base practically all of their processes on solar energy, its conversion into plant biomass and, consequently, agriculture as the key energy supply sector, or if they base their processes on fossil fuel energy sources. In the first case, societies as a whole absolutely depend on a positive high EROI (energy return upon energy investment ${ }^{3}$ ) from agriculture, and if it is low, such societies are constrained in their complexity. In the second case, they can afford to subsidise agriculture energetically. For agriculture, the subject of much of Boserup's writing, this makes a huge difference, a qualitative leap beyond what she introduces as gradual distinctions. In the following paragraph, we will explain how we, building upon Boserup's ideas, argue the need for drawing a qualitative distinction between what we call agrarian and industrial sociometabolic regimes.

\footnotetext{
${ }^{3}$ On the concept of EROI, see (Hall et al. 1986, p. 28)
} 


\subsection{Understanding Qualitative Change: Sociometabolic Regimes}

The metabolism of all pre-industrial societies is based on the use of biomass and thus upon the ability of plant organisms to utilise solar energy via photosynthesis to create energy-rich material from carbon dioxide, water and mineral compounds. In the form of nutrition and animal feed, biomass provides the energetic basis for sustaining the existence of humans and their livestock and can be converted into mechanical energy. Combustion (burning fuelwood, for example) provides space and process heating for domestic households (cooking), mining (metal smelting) and light. The conversion of heat into mechanical energy was not possible prior to the invention of the steam engine; thus, the availability of mechanical energy was subject to strict limitations. Water and wind power play an important yet very much subordinate role in terms of quantity. With few exceptions, ${ }^{4}$ biomass was by far the most important energy source until the industrial revolution, generally accounting for $99 \%$ of all available primary energy.

The production of available energy is based upon the controlled transformation of ecosystems by labour with the aim of increasing the utilisable yield of biomass; i.e., upon the colonisation of nature. The basic precondition for this form of subsistence is that a positive energy yield (EROI) is obtained from agrarian activity; through agrarian land-use, significantly more energy in the form of biomass must be produced than is expended in the form of human labour (and prerequisite energetic expenditures such as nutrition). It has been estimated that in Central Europe before the beginning of industrialisation in the agrarian economy, an EROI of c. 10 to 1 was achieved (Krausmann 2004; Leach 1976). Any surplus may be used to supply the non-agrarian sectors of society - that is, to provide nutrition and fuelwood for urban centres, as well as feed for the draught animals that have to transport all this material.

The higher the surplus, the more complex the possible societal structures become. However, this surplus is never particularly high because a system must be very well organised for the work of 10 farm families to be able to sustain more than 1-2 other households (such as aristocratic landowners, craftspeople or bureaucrats). Under the agrarian regime, reactions to increases in food demand, which are usually caused by population growth, initially involve expanding the area dedicated to agrarian production - and this may often lead to attempts to capture new territories. As a last resort, where land is scarce and territory limited, the option remains to apply a greater investment of labour to the same land area with the aim of achieving a greater yield, in other words, the intensification of land-area use. However, the yield per invested hour of labour declines as intensity of use increases and asymptotically approaches a physical limitation, from which point there is no benefit to be achieved by further

\footnotetext{
${ }^{4}$ In the seventeenth century in the Netherlands, for example, the exploitation of large peat deposits, intensive use of wind energy and a dense network of waterways suitable for shipping formed the energetic basis for an exceptional economic development, the Dutch Golden Age. It is estimated that during this period, up to 1.5 million tonnes of peat were dug annually, involving the excavation of 700 ha of peatland each year. Peat is a source —albeit not one of the oldest—of fossil energy. See (De Zeeuw 1978).
} 
intensification. In other words, growth is possible but leads to a diminishing marginal utility of labour. When this limit is reached, we find the "typical" picture of agrarian societies, in which the majority of the population, including children, incessantly performs demanding physical work while still suffering from shortages of essential resources. This logic, which Ester Boserup has studied on a worldwide basis and of which she provides a detailed description, represents a fundamental limitation of societal development in agrarian regimes: as a rule, growth in this regime eventually leads, despite progress made regarding methods of husbandry and plant cultivation, to the stagnating or even diminishing availability of per capita material and energy resources.

Furthermore, the absence of the possibility to transform heat energy into mechanical work limits the degrees of freedom. Mechanical work can only be performed through the physical work of humans, animals and water/wind energy; thus, the productivity that was thereby attainable remained relatively low. ${ }^{5}$ Altogether, the size and structure of societal metabolism and its spatial differentiation were subject to limitation through the controlled solar energy system. In Europe, before the beginning of the Industrial Revolution, 2-4 t of raw material and 30-70 gigajoules (GJ) ${ }^{6}$ of primary energy were appropriated per capita and year, whereby biomass accounted for over $80 \%$ of all material and $95 \%$ of all energy inputs: food for human populations, livestock feed and wood for construction and fuel. Regional differences in metabolism were related in particular to the varying relevance of holding livestock and climatic conditions. ${ }^{7}$

Starting in seventeenth century England, increased use of coal led to the development of a new energy system. At the core of this energy transition was a transition from the use of energy flows with low power density in the form of biomass that is regrown annually to the exploitation of large-scale energy deposits that had accumulated over geological eras and existed in a concentrated form as coal, with a high power density (Smil 2003). Initially, coal was used solely as an often quite unpopular fuel for stoves in the households of manufacturing workers in urban centres, whose increasing requirements could not be supplied by fuelwood alone. Fortunately, coal supplies in England were found close to these centres, and coal could also be transported at low cost via waterways. ${ }^{8}$

\footnotetext{
${ }^{5}$ One should imagine that a Pharaoh with 2000 labourers to build the pyramids had little more capacity at his disposal as a worker would today using a large road construction machine.

${ }^{6}$ One Joule represents 0.24 calories and is a very small unit. A megajoule $(\mathrm{MJ})=10^{6} \mathrm{~J}$, a gigajoule $(\mathrm{GJ})=10^{9} \mathrm{~J}$ and an exajoule $(\mathrm{EJ})=10^{18} \mathrm{~J}$. The energy content (calorific value) of $1 \mathrm{~kg}$ of wood is roughly $15 \mathrm{MJ}$, that of coal is $20-30 \mathrm{MJ}$ and that of petroleum is $45 \mathrm{MJ}$.

${ }^{7}$ The highest biomass conversion rates are seen in pastoral societies with a very high per capita livestock holding and the lowest are recorded in societies whose means of subsistence rely predominantly on human physical work and plant-based diets (for example, in the rice-cultivating societies of south and southeast Asia).

${ }^{8}$ These densely populated manufacturing centres had come into existence because, as early as the seventeenth century, the English owners of large estates found it more profitable to use their land for the production of the raw materials of the textile industry than to produce foodstuff for a rural population, which, in their eyes at least, was seen as partly expendable.
} 
In nearly all other world regions, by contrast, only regional urban-industrial centres were affected by this metabolic transition. Accordingly, the average per capita coal use remained negligible in countries such as India, China or Brazil even at the beginning of the twentieth century, comprising far less than $100 \mathrm{~kg} /$ capita and year. Indeed, the European countries that were in the process of industrialising had an active interest in using colonialism to ensure that other world regions played a role as suppliers of cheap agricultural products and other raw materials, as well as outlet markets for growing industrial production and certainly not in allowing them to participate in industrial development themselves (see further discussion on this theme below).

Later, steam engines enabled the conversion of coal into mechanical power, which led to a dramatic increase in the available capacity compared to what had existed under the previous regime. The possibility of extracting, transporting, processing and consuming materials underwent radical change, and an entirely new form of societal metabolism came into being as a result. In addition to biomass, huge quantities of coal, construction materials and ore were extracted and processed. In the United Kingdom, materials used, for example, increased from 60 to 400 million tonnes per year between 1750 and 1900. Population growth during this phase happened at a somewhat slower pace than the increase in material and energy use. For the first time in history, there was rapidly growing demand for non-agricultural workers. The mechanical performance of large coal-powered machines created conditions that produced an immense number of jobs required for final manufacturing. During this phase, although there was a rise in per capita material and energy consumption, it did not produce an increase in mass prosperity but was instead channelled into the expansion of the factory system and into exports.

Coal represented a first important step towards emancipating the energy system from the land area and removing traditional limitations on economic growth. Rolf Peter Sieferle coined the vivid phrase "subterranean forest" for this phenomenon (Sieferle 1982). He showed that the energy (calorific value) contained in the amount of coal that was combusted annually in the United Kingdom by 1850 had already reached the equivalent of the fuelwood that could be produced from a virtual forest area the size of the entire country. By 1900, this amount had risen to an area equivalent to a subterranean forest covering four times the land area of the entire country (see Fig. 3.4). We may interpret this finding to mean that to maintain societal metabolism at the same level, the United Kingdom would have required a territory four times greater than its actual land area and entirely covered in forest for use.

However, coal use did not remove all the limitations of the solar energy system. A very profound reliance upon the area-dependent resource of biomass remained in place: the need for nutrition. Access to more (technical) energy had not in any sense replaced human physical work but in fact had increased the demand for labour power in need of nutrition. In a similar way, the railway did not replace the need for draught and working animals; on the contrary, the wide-meshed network of railway lines, in combination with an increase in transported goods and people, led to an increasing demand for working animals. Stocks of draught animals grew continuously into the twentieth century. Similarly, coal did indeed provide a substitute for fuelwood, 
Fig. 3.4 Coal use in the United Kingdom (UK) as virtual forest area.

(Source: Krausmann and Fischer-Kowalski 2012, p. 346 , according to Sieferle 1982). Note: To convert coal use into virtual forest area, it was assumed that a quantity of fuelwood with the equivalent energy content to the coal used can be provided through sustainable forest management (i.e., through the use of annual growth and not standing timber mass). The forest area required to produce this volume of fuelwood is presented as a virtual forest area.)

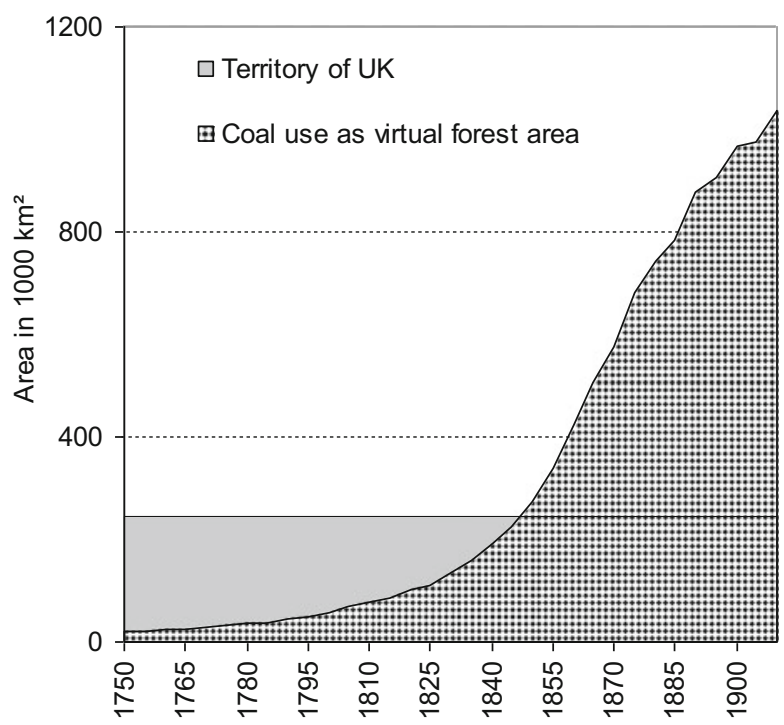

but more timber than ever before was required for building the railways and for the emerging paper industry. Altogether, the demand for biomass grew paradoxically alongside the transformation of the energy system to feed people and animals and to supply new industries with raw material. At the same time, the potential for expanding the cultivatable area was largely exhausted, and the means of raising area productivity were limited. The most important limitation was the chronic shortage of fertiliser. Although mineral fertilisers, such as guano, Chile saltpetre and superphosphate, were increasingly used in agriculture by the end of the nineteenth century, the volumes employed were low and limited to special crops such as oranges or tobacco and the supply of plant nutrients for most of the cultivated land still had to rely on farm-internal means (manure, leguminous crops, etc.). Thus, a fundamental limitation upon traditional agriculture remained in place, which, in spite of successful biological innovations such as new cultivated plants and new land-use practices, led to stagnating grain yields in the nineteenth century.

In the USA, a completely different development took place; a rapidly growing population but an extremely low population density of only 2 persons per $\mathrm{km}^{2}$ meant that with the expansion of the railway system, huge swathes of fertile prairie land could be cultivated for food production. Within a few decades of homesteading, over 100 million ha of high-quality agricultural land were gained in the Midwestern USA between 1850 and 1920, after the indigenous peoples, with their extensive landuse practices, had been violently expelled (Cunfer 2005). The nutrient-rich soils of the Great Plains allowed for high initial yields with little labour input. The labour productivity of this system of agriculture was extraordinarily high and enabled a small rural population to supply the densely populated urban centres on the coasts as well as to export large quantities of foodstuff to Europe. By around 1880, the USA was already exporting over 4 million tonnes of grain, providing basic nutrition for over 20 million people (Krausmann and Cunfer 2009). 

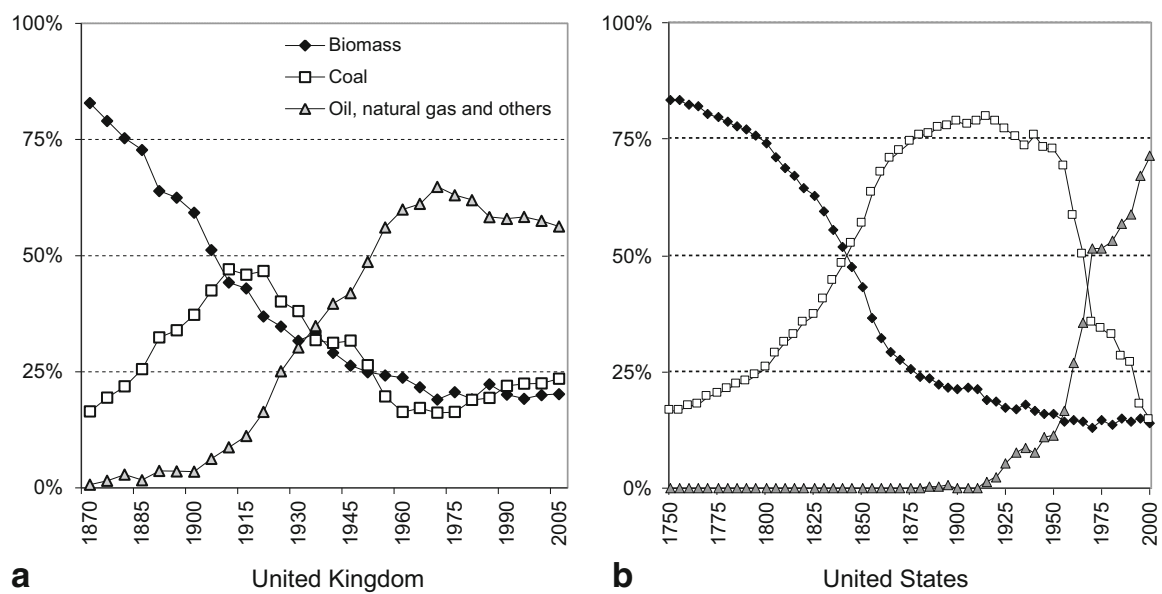

Fig. 3.5 The establishment of new energy sources in the United Kingdom (1870-2006) (a), and the United States (1750-2000) (b). (Data sources: Authors' calculations based on Schandl and Krausmann 2007, p. 97 (United Kingdom), and IEA 2008; Krausmann et al. 2009; Podobnik 1999). Note: In this diagram, the share of the total primary energy supply, represented by the three fractions of biomass, coal and oil/natural gas (including other energy forms), is depicted. The biomass fraction includes all biomass used as food for humans and livestock and biomass used for all other purposes, together with fuelwood

Not only the agrarian productivity of a pioneer country but also another resourceoil-positioned the USA to become the leading nation during the next phase of the industrial transformation (Fig. 3.5).

\subsubsection{The Green Revolution}

As shown, in the nineteenth century, the USA was able to effectively compensate the weaknesses of the English transformation model (i.e., difficulties in producing sufficient food for a high-density and growing population) and to turn this to its advantage. However, it became clear that this level of agricultural productivity had no long-term potential and after only a few decades, ran up against massive ecological limitations. The combination of large land areas with a low investment of labour was only possible because the prairie soil, then being ploughed for the first time, contained huge reservoirs of plant nutrients accumulated over a long historical period. These reservoirs, however, quickly began to deplete in the first decades of ploughing. The yields began to decrease, and enormous problems with erosion appeared (Cunfer 2005). However, in a situation where oil could be obtained cheaply and with a bundle of technologies coupled to this new energy source, a new and successful agricultural model was possible. The tractor allowed for the substitution of all animal labour and a large proportion of human labour in agriculture, much as the motor saw raised the speed of tree-felling in comparison with the axe by a factor of 100-1,000 (and thus 
enabled the rapid deforestation of the rainforests). The agrochemical industry, based on petroleum and natural gas, helped to lift the chronic limitations on plant nutrients from which agriculture was suffering. From the 1920s onwards, huge amounts of atmospheric nitrogen were made available for agricultural use using the Haber-Bosch process, which requires a high energy input (Smil 2001). The average nitrogen application in crop farming increased to several $100 \mathrm{~kg} / \mathrm{ha}$ as a result. Together with industrial potassium, phosphate fertilisers, pesticides and successes in plant and livestock breeding, area yields and labour productivity in agriculture were amplified within a very short space of time (Grigg 1992).

Starting in the USA and disseminated by agricultural companies active on the global market, these new agricultural methods were spread around the world under the term green revolution. ${ }^{9}$ They found application in Europe after World War II. As a result, the proportion of the population engaged in agriculture fell to $5 \%$ or less. The green revolution also took hold in large sectors of agriculture in the southern hemisphere and helped create conditions in which global food production was able to keep pace with the quadrupling of the world population in the twentieth century.

The industrialisation of agriculture required a massive transformation of the agrarian landscape, which had to be rendered suitable for machine activity. This transformation led to a range of specific environmental problems. The position of agriculture in societal metabolism and the energy system changed fundamentally. Industrialised agriculture requires a high energy input, and today, more energy is invested in agricultural production than is subsequently obtained in the form of food, which is partly due to the large quantity of high-quality agricultural produce that is fed to livestock. In general, agriculture has been altered during the course of the sociometabolic transformation from being the most important source of useful energy to becoming an energy sink (Pimentel and Pimentel 1979). With the industrial transformation, society has made itself dependent on abundant external energy sources for the most important part of its metabolism, namely, the feeding of its population.

This industrial stage of agriculture does not comply with Boserup's theory of population growth driving technological innovation and leading to a substitution of natural resources by labour and capital. Bringing a completely new natural resource into play introduces a completely new pattern.

\subsection{Examples of Later Research Findings that Could Have Been Anticipated from Boserup's Theory}

\subsubsection{Example 1: On the Non-Linearity Between Population and Land Requirement}

One of Boserup's core ideas is inspirational: the anti-Malthusian message of a nonlinear relationship between the (growing) number of people and land requirement,

\footnotetext{
${ }^{9}$ The term green revolution was first coined in 1968 by William S. Gaud, the director of the United States Agency for International Development USAID. See also (Leaf 2004).
} 

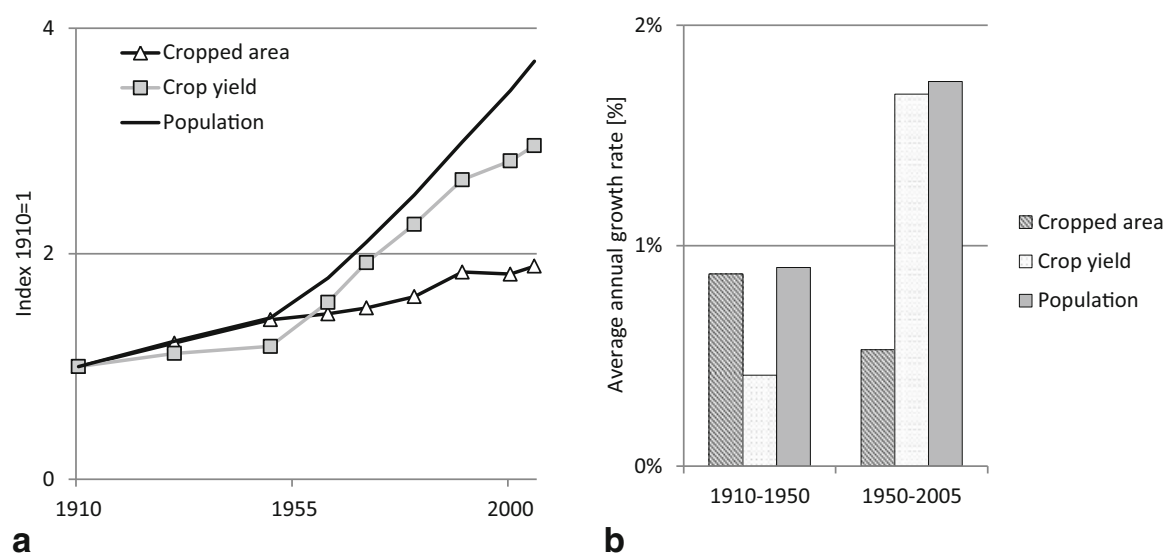

Fig. 3.6 Development of global cropped area, average crop yields per unit area and population in the twentieth century. Indexed Development from 1910 to $2005(1910=1)(\mathbf{a})$, and average annual growth rates for the period 1910-1950 and 1950-2005 (b). (Based on Krausmann et al. 2013). Note: Since the green revolution, these changes have been achieved not by increasing human labour inputs (on the contrary, the number of people globally working in agriculture has decreased) but by increasing labour input in its technical form, namely direct or indirect energy input on the basis of fossil fuels

with the key intervening variable being the intensification of use. This proposition held on a global level throughout the twentieth century (Fig. 3.6). One must assume, though, that generating more output on the same cropland was achieved by different methods before and after the green revolution, with its fossil fuel-based inputs and tools. Whereas before the green revolution, the mechanisms described in Boserup (1965), namely reduced fallow periods and, in extreme cases, shifting to multicropping, at the expense of increasing labour investment, presumably dominated and achieved an increase in output that could not quite keep up with population growth (so that there still had to be a substantial expansion in cropland), after the green revolution (i.e., from the late 1950s onward), the growth in yields far exceeded the growth in cropland. In the most recent decades, however, yields have again grown at a slower pace than the world population (Fig. 3.7).

During the heyday of the green revolution, the number of tractors increased twoand-a-half fold, and the use of mineral fertilisers increased fivefold. Again, we see a structural break from the late 1980s onward in which these inputs have stagnated and the overall energy input in agriculture dropped and has remained stable on a substantially lower level. If we relate this to the results shown in Fig. 3.8, it is apparent that rises in crop yields and rises in fossil fuel-based inputs relate closely. No doubt this may change again in the future; the increasing prices of fossil fuels (and maybe even outright oil scarcity) and agricultural products may create a situation in which more labour-intensive forms of agriculture regain their place in society.

One international mistake could have been avoided by looking more closely at Boserup's works. The original global estimates of land available for biofuels ("unused 
Fig. 3.7 Global trends in agricultural inputs 1961-2005. (Source: FAO 2007; IEA 2008. Note: The number of tractors is a conservative estimate for the input of labour, as the size of tractors has increased considerably since 1961.)

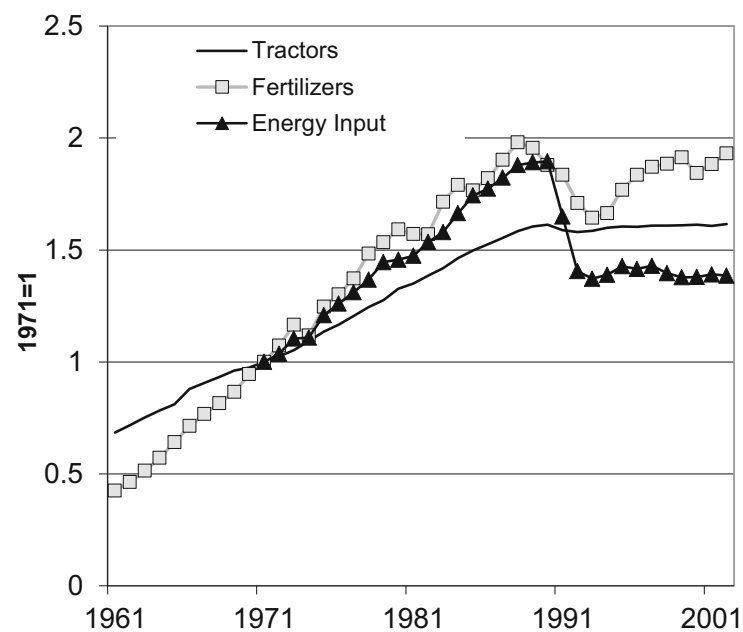

land") were much too high (Haberl et al. 2010 provide an excellent overview). Boserup would have taught them that on this populated planet, there is no such thing as "unused land" (regardless of what it looks like on satellite images); the intensity of land use is a matter of degree, with-for example-extensive pastures contributing essentially both to the nutrition of people and to the fertilization of their cropland.

\subsubsection{Example 2: Generalizing the Thesis of Non-Linearity to Other Resources}

An analogous argument may apply to the human use of other natural resources as well: although population numbers are one of the strongest drivers of the requirement of energy and material resources, technological innovations allow, through
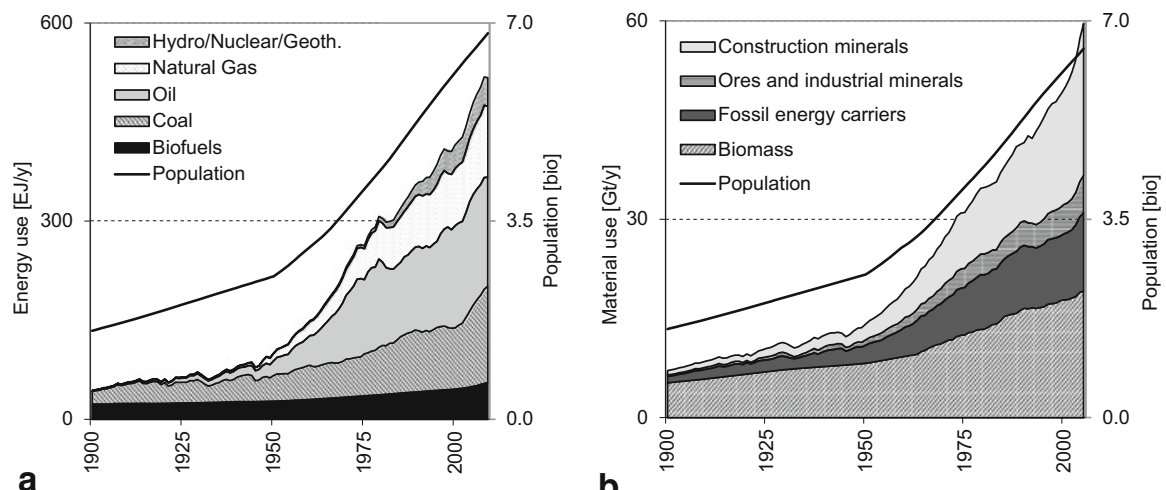

b

Fig. 3.8 Global primary energy use (a), and material use (b), 1900-2010. (Source: Krausmann et al. 2009) (data update 2011) 
increasing efficiency, a certain degree of non-linearity in this relationship. Under the agrarian sociometabolic regime (or agricultural societies, as Boserup would say), an increasing population density allowed for urbanization, and urbanization both offered the conditions for further technological development and required them (such as fortifications, new means of transport and transport infrastructures, new weapons, etc.). However, urbanization and a lifestyle beyond the daily toil of agriculture was clearly limited by the low agricultural surplus that could be taxed from peasants, limits to transportation (land transport for bulky materials could only cover a few kilometres; ships were the only viable alternative), and limits to timber and fuel wood that used to be quickly exhausted in the vicinity of urban centres. (See part II in Boserup 1981, pp. 15-92; see also Sieferle 1982) Thus, once the basic infrastructural investments were completed, the requirements of natural resources (food, feed, timber and fuelwood, fibres, clay, metals and mineral building materials) grew at most at the pace of the population and, one may speculate, maybe often below for scarcity and efficiency reasons. There was a certain built-in mechanism for territories to grow but not a built-in mechanism for individual consumption to grow. ${ }^{10}$

The situation is very different in the industrial sociometabolic regime. There, technological innovations mainly reduce labour requirements and drive income (Ayres and Warr 2009). The more resources for a certain service are saved through innovation, the more resources are consumed overall (Sorrell and Dimitropoulos 2008). During all of the twentieth century, marked by the expansion of the industrial regime, the global resource consumption of energy and all other materials increased much faster than the already very steep rise of the world population (see Fig. 3.8). In effect, per capita consumption of natural resources almost tripled during this century, and it is continuing to rise as the industrial regime expands to more and more countries.

All this could not have happened with biomass as the core source of energy. Industrial agriculture uses large amounts of fossils to boost annual harvests of net primary production by an order of magnitude (Haberl et al. 2007).

The rise of per capita energy and materials consumption, i.e., the non-linearity of resource requirements with elasticities above 1 in relation to population growth, is particularly pronounced in two phases (see Fig. 3.9). One phase is the period between the world economic crisis in 1930 and the first oil crisis in 1972-this is precisely the period of booming oil in the US, reconstruction after World War II in Europe, and the worldwide spread of the so-called green revolution in agriculture (Pimentel et. al 1973). The other phase has been visible on a global level since the turn of the twentyfirst century, but regionally started much earlier: the rapid industrial transformation, on a fossil fuel base, of a number of so-called emergent economies such as China, Brazil, Korea or India.

The first decade of the new century was marked by a shift in resource prices; for the first time in many decades, there was a steep trend upward (the long-term trend had always been declining) for oil and gas, cereals, and many metals and minerals. In the

\footnotetext{
${ }^{10}$ For the elites, growth of territory, of course, was the major mechanism for becoming richer; however, compared to today, differences in consumption levels between the rich and the richer were negligible.
} 
Fig. 3.9 Per capita global energy and materials use during the twentieth century. (Source: Krausmann et al. 2009) (data update 2011)

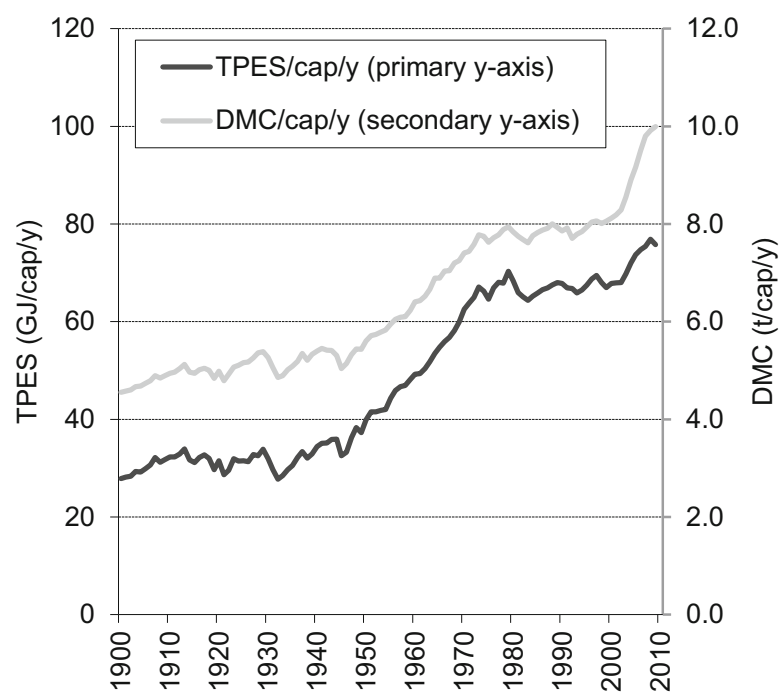

same decade, a major global financial crisis (which also exists today) and structural shifts in world trade occurred (Dittrich and Bringezu 2010). If Ester Boserup had had the chance to use these sociometabolic indicators for her analysis, what conclusions would she have come up with? Would she have been able to maintain her generally positive outlook on population growth and technological advancement?

\subsubsection{Example 3: On the Role of Development and Population Density in Driving Resource Use}

Development, in the sense of a transition from an agrarian to an industrial regime, implies a much more substantial increase in resource use than Boserup could be aware of. On the basis of a number of historical and contemporary case studies, several authors (Haberl et al. 2011; Krausmann et al. 2008) published the following estimates (Table 3.1). Primary energy use ${ }^{11}$ per capita has increased by a factor between 3 and 5, far beyond the range of any agrarian society; biomass use, although absolutely not decreasing, only supplies 10-30\% of the energy used. The same holds true for materials use-with the energy available, 3-5 times as much material can be mobilised. In addition, the fraction of the population working in agriculture has decreased from above $80 \%$ to less than $10 \%$. With the demographic transitions that have come along, population density has increased 3- to 10-fold, leading to a very

\footnotetext{
${ }^{11}$ Measured as Domestic Energy Consumption (DEC), which includes, beyond the primary energy from commercial sources as measured by TPES (total primary energy supply), the food and feed energy consumed. Thus, it is a much better indicator for comparing energy requirements across historical periods in which food/feed energy comprised most of the energy used.
} 
Table 3.1 Comparing the agrarian and the industrial regime: Population density, per capita resource use and agricultural population. (Source: Krausmann et al. 2008)

\begin{tabular}{lllll}
\hline & & Agrarian & Industrial & Factor \\
\hline Energy use (DEC) per capita & {$[\mathrm{GJ} / \mathrm{cap}]$} & $40-70$ & $150-400$ & $3-5$ \\
Energy use (DEC) per area & {$[\mathrm{GJ} / \mathrm{ha}]$} & $<30$ & $<600$ & $10-30$ \\
Biomass (share of DEC) & {$[\%]$} & $>95$ & $10-30$ & $0.1-0.3$ \\
Material use (DMC) per capita & {$[\mathrm{t} / \mathrm{cap}]$} & $3-6$ & $15-25$ & $3-5$ \\
Material use (DMC) per area & {$[\mathrm{t} / \mathrm{ha}]$} & $<2$ & $<50$ & $10-30$ \\
Population density & {$\left[\mathrm{cap} / \mathrm{km}^{2}\right]$} & $<40$ & $<400$ & $3-10$ \\
Agricultural population & {$[\%]$} & $>80$ & $<10$ & 0.1 \\
\hline
\end{tabular}

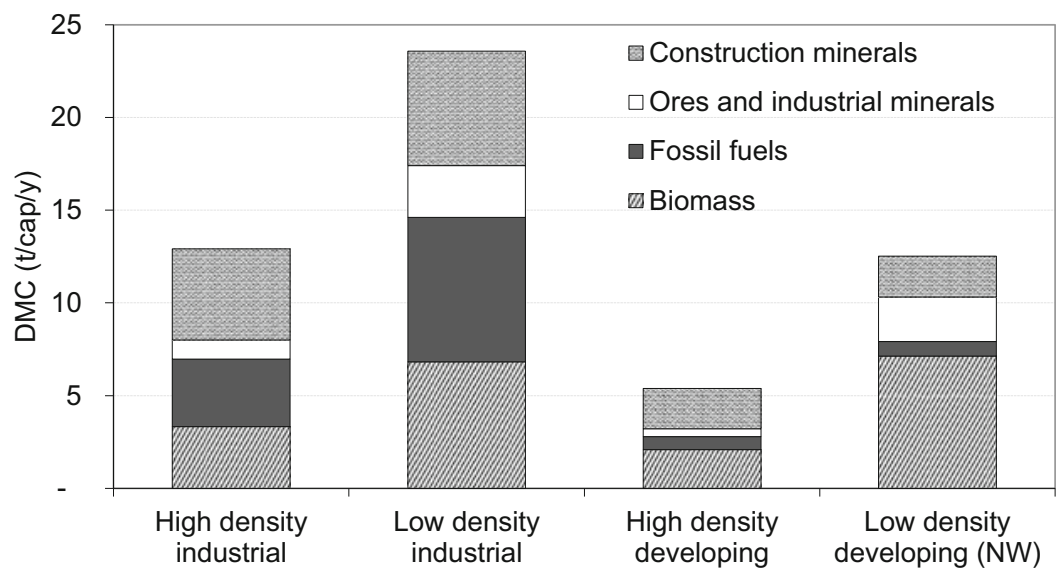

Fig. 3.10 The combined effect of development status and population density on per capita material use (175 countries in the year 2000). (Based on Krausmann et al. 2008)

strong increase in the impact (or, rather, pressure) of humans per unit area. The Boserupian idea that humans, specifically because of a higher density (and therefore rising collaboration and inventiveness), could be able to buffer the negative impacts of their increasingly intensive use upon the environment was partly true as far as local and regional impacts in rich countries are concerned but not on a global or long-term scale.

On a global level, nevertheless, the mitigating effect of population density can be demonstrated. Both among developing (i.e., in the middle of a transition from agrarian to industrial in the year 2000) and among fully industrialised countries, countries with above-average population densities are able to provide their people's welfare at a substantially lower level of per capita consumption of natural resources (Fig. 3.10). This finding relates to different patterns of (historically evolved) lifestyle and consumption. Densely built urban centres, for example, demand much less infrastructure materials for supply, disposal and transportation (Weisz and Steinberger 2010), as well as less energy for heating and transport, than scattered settlements. In the same vein, densely populated regions tend to develop a diet that is not as resource (and area) demanding as the diet in regions where there is plenty of food available. 
In the opposite direction of causality, one finds natural resources (such as timber, or mining products) being extracted preferably in low density areas, which boosts the metabolic rates in these regions. High density areas are instead only the consumers of these resources, and the "upstream flows" do not weigh on their metabolic rates.

This difference was considered so striking that UNEP based its scenarios of future resource use on the assumption that developing countries, over the coming decades, would tend to emulate the metabolic rates of industrial countries but maintain differences according to population density (UNEP 2011). Nevertheless, the IRP came to the conclusion that the already ongoing continuation of metabolic convergence would lead to an untenable level of global resource use, running up not only against all climate concerns but also against global resource constraints (fossil fuels, metals). Thus, Boserup, in contrast to most of her contemporaries, correctly viewed population growth and density increase not just as rising but also as alleviating environmental burdens.

\subsection{Conclusion}

Although Ester Boserup, in both her 1965 book and her 1981 book, provides one of the most subtle and theoretically profound descriptions of the dynamics of agricultural societies, she fails to perceive the qualitative differences introduced by the use of fossil fuels. Her trust in human ingenuity makes her overlook the possibility of a substantial overshoot of human use of resources beyond what the earth system may provide us in the long run. Writing her later book a few years after Limits to Growth by Meadow et al., she makes no reference to this work, as she had not done in her first book to Rachel Carson's Silent Spring (although the two women were personally in contact $^{12}$ ). Her personal engagement in favour of development opportunities, her strong anti-Malthusian sentiment and her theoretical roots in classical political economy did not allow her to see something obvious: that the widespread use of fossil fuels disrupted the logic of the agricultural society so well analysed by her, and that it created a new dynamic that may eventually eradicate the natural conditions for human welfare on the Earth.

Open Access This chapter is distributed under the terms of the Creative Commons Attribution Noncommercial License, which permits any noncommercial use, distribution, and reproduction in any medium, provided the original author(s) and source are credited.

\footnotetext{
${ }^{12}$ According to personal communication with Faye Duchin.
} 


\section{References}

Ayres, R. U., \& Warr, B. (2009). The economic growth engine: How energy and work drive material prosperity. Cheltenham: Edward Elgar.

Boserup, E. (1965). The conditions of agricultural growth: the economics of agrarian change under population pressure. Chicago: Aldine, Earthscan.

Boserup, E. (1981). Population and technological change: a study of long-term trends. Chicago: University of Chicago Press.

Cunfer, G. (2005). On the great plains: Agriculture and environment. College Station: Texas A \& M University Press.

De Zeeuw, J. W. (1978). Peat and the Dutch Golden Age. A. A. G. Bijdragen, 21, 3-31.

Dittrich, M., \& Bringezu, S. (2010). The physical dimension of international trade. Part 1: Direct global flows between 1962 and 2005. Ecological Economics, 69(9), 1838-1847.

FAO (Food and Agriculture Organization of the United Nations). (2007). FAOSTAT, FAO Statistical Databases: Agriculture, Fisheries, Forestry, Nutrition.

Grigg, D. B. (1992). The transformation of agriculture in the West. Oxford: Blackwell.

Haberl, H., Fischer-Kowalski, M., Krausmann, F., Weisz, H., \& Winiwarter, V. (2004). Progress towards sustainability? What the conceptual framework of material and energy flow accounting (MEFA) can offer. Land Use Policy, 21(3), 199-213.

Haberl, H., Erb, K., Krausmann, F., Gaube, V., Bondeau, A., Plutzar, C., et al. (2007). Quantifying and mapping the human appropriation of net primary production in earth's terrestrial ecosystems. Proceedings of the National Academy of Sciences of the United States of America, 104(31), $12942-12947$.

Haberl, H., Beringer, T., Bhattacharya, S. C., Erb, K., \& Hoogwijk, M. (2010). The global technical potential of bio-energy in 2050 considering sustainability constraints. Current Opinion in Environmental Sustainability, 2(5-6), 394-403.

Haberl, H., Fischer-Kowalski, M., Krausmann, F., Martinez-Alier, J., \& Winiwarter, V. (2011). A socio-metabolic transition towards sustainability? Challenges for another Great Transformation. Sustainable Development, 19(1), 1-14.

Hall, C. A. S., Cleveland, C. J., \& Kaufmann, R. (1986). Energy and resource quality: The ecology of the economic process. New York: Wiley Interscience.

IEA (International Energy Agency). (2008). Energy statistics of non-OECD countries. IEA, Organisation of Economic Co-Operation and Development (OECD). http://www.iea.org. Accessed 10 Jan 2008.

Krausmann, F. (2004). Milk, manure and muscular power: Livestock and the industrialization of agriculture. Human Ecology, 32(6), 735-773.

Krausmann, F., \& Cunfer, G. (2009). Agroecosystems on the American frontier: Material and energy systems and sustainability. Presentation at the World Congress of Environmental History, Copenhagen. August, 4-8, 2009.

Krausmann, F., \& Fischer-Kowalski, M. (2012). Global socio-metabolic transitions. In S. J. Singh, H. Haberl, M. Chertow, M. Mirtl \& M. Schmid (Eds.), Long term socio-ecological research: Studies in society-nature interactions across spatial and temporal scales. Human-environment interactions (Vol. 2, pp. 339-365). Dordrecht: Springer.

Krausmann, F., Fischer-Kowalski, M., Schandl, H., \& Eisenmenger, N. (2008). The global sociometabolic transition. Journal of Industrial Ecology, 12(5-6), 637-656.

Krausmann, F., Gingrich, S., Eisenmenger, N., Erb, K., Haberl, H., \& Fischer-Kowalski, M. (2009). Growth in global materials use, GDP and population during the 20th century. Ecological Economics, 68(10), 2696-2705.

Krausmann, F., et al. (2013). Global human appropriation of net primary production doubled in the 20th century. Proceedings of the National Academy of Sciences of the United States of America, 110(25), 10324-10329. doi:10.1073/pnas.1211349110.

Leach, G. (1976). Energy and food production. Guildford: IPC Science and Technology Press. 
Leaf, M. J. (2004). Green revolution. In S. Krech III, J. R. McNeill \& C. Merchant (Eds.), Encyclopedia of world environmental history (Vol. 2 pp. 615-619). London: Routledge.

Pimentel, D., \& Pimentel, M. (1979). Food, energy and society. London: Arnold.

Pimentel, D., et al. (1973). Food production and the energy crisis. Science, 182(4111), 443-449.

Podobnik, B. (1999). Toward a sustainable energy regime: A long-wave interpretation of global energy shifts. Technological Forecasting and Social Change, 62(3), 155-172.

Schandl, H., \& Krausmann, F. (2007). The great transformation: A socio-metabolic reading of the industrialization of the United Kingdom. In M. Fischer-Kowalski \& H. Haberl (Eds.), Socioecological transitions and global change: Trajectories of social metabolism and land use (pp. 83-115). Cheltenham: Edward Elgar.

Sieferle, R. P. (1982). Der unterirdische Wald: Energiekrise und Industrielle Revolution. Munich: Beck.

Smil, V. (2001). Enriching the earth: Fritz Haber, Carl Bosch, and the transformation of world food production. Cambridge: MIT Press.

Smil, V. (2003). Energy at the crossroads: global perspectives and uncertainties. Cambridge: MIT Press.

Sorrell, S., \& Dimitropoulos, J. (2008). The rebound effect: Microeconomic definitions, limitations and extensions. Ecological Economics, 65(3), 636-649.

UNEP (United Nations Environment Programme). (2011). Decoupling natural resource use and environmental impacts from economic growth: A report of the Working Group on Decoupling to the International Resource Panel. Authors: Fischer-Kowalski, M. et al. Nairobi, Kenya: UNEP.

Weisz, H., \& Steinberger, J. K. (2010). Reducing energy and materials flows in cities. Current Opinion in Environmental Sustainability, 2(3), 185-192. 